\title{
ROLE OF ICT IN ENHANCING THE PERFORMANCE OF THE TEACHING STAFF IN HIGHER INSTITUTIONS IN SUDAN UNIVERSITY OF BAHRI AS A CASE STUDY
}

\author{
Hashim Abdelgadir Elbakhit Ahmed \\ Ph.D. Faculty of Education University of Bahri- Sudan, hashim623@yahoo.com
}

\begin{abstract}
Information and communication technologies (ICT) can be used to support and enhance teaching and learning process. The following ICT tools: computer, video conference, projector, mic and other technologies have been used in classrooms. These tools deliver different types of contents and serve various purposes in the lecture hall. This empirical research aims at finding out (a) the real situation of ICT used in the higher institutions in Sudan. (b) to explore solutions to overcome challenges of ICT use (c) come up with specific recommendations can be generalized to all universities throughout the country in regard to ICT use. Structured questionnaire was designed to obtain primary data, in addition to secondary data collected from references and internet. It presents results of a survey to a number of 74 of teaching staff representing eight faculties at University of Bahri - Sudan. The findings of this study revealed that teaching staff had a strong willingness to integrate ICT into teaching-learning processes. The innovations that ICT has brought in teaching and learning process come through presentation via computer (PPT), video conference, social networks, e-courses, internet, email to communicate with students. Moreover, the existence of all these media increased the opportunity to excellent practice of teaching-learning process. The study introduced the following recommendations; equipping the lecture halls with the suitable digital equipment to enable teaching and learning with computer programs, developing new curricula for applying the ICT as presentation tools, encouraging ICT use by teaching staff accompanied by training and capacity development, integrating the ICT use into the university strategy, and finally transformation of positive attitudes towards ICT into effective practices.
\end{abstract}

Keywords: ICT, Enhancing, Teaching-Learning, Teaching Staff

\section{INTRODUCTION}

The use of ICT in education is covering behind expectation and desire. The role of ICT can support this process which focuses on capacity building of teacher. Guma, et al.(2013) argue that, the use of ICT in the classroom teaching-learning is very important for it provides opportunities for teachers and students to operate, store, use, and retrieve information, encourage independent and active learning, and selfresponsibility for learning such as distance learning, motivate teachers and students to continue using learning outside school hours, plan and prepare lessons and design materials such as course content 
delivery and facilitate sharing of resources. The nature and extent to which ICT is being used in education is considered to be vital. In spite of all efforts made, the use of ICT in higher education institutions (HEIs) in general is poor. (Smeets, et al. 1999) stated that high expectations with regard to the potential of computer in education have not been met. Initially, attempts to introduce the computer in education were technologycentred, the role of the teacher in the innovation process being ignored. These innovators tended to view teachers as organisers of prescribed tasks, indicating that detailed tasks had to be formulated in order to get teachers to use computer in the classroom.

University of Bahri is considered one of the newest universities in Sudan was established in July 2011 to accommodate northern Sudanese citizens who were working and/or studying in the former southern national universities, following the separation of South Sudan from the North to form an independent Country. The University of Bahri is built on a strong foundation of academic excellence and relevance through highly experienced academic and supporting staffs, therefore it looks to be a leader in higher education inside and outside the Sudan, particularly in the field of integration the ICT into learning and teaching process.

\section{OBJECTIVES}

The specific objectives of the study are to: -

1. Determine factors influencing use of ICT to make teaching-learning effective in higher institutions in Sudan.

2. Identify the situation of using ICT in teaching-learning process among the academic staff of University of Bahri.

3. Come up with recommendations can be generalized to higher education institutions throughout the Sudan regarding to the ICT use.

\section{RESEARCH QUESTIONS}

1. Do you use the computer for presentation in the teaching process?

2. Do you use information and communication technology (ICT) in the teaching and learning process?

3. If yes, please rank the following tools according to your use?

Websites ( ) social networks ( ) projector ( ) email ( ) forums ( ) chat ( ) WhatsApp ( )

E- Courses ( )

4. Do you think that, the use of ICT enhances the teaching and learning process?

\section{DEFINITION OF ICTS}

ICT is a broad term referring to technologies which are being used for collecting, storing, editing and passing on information in various forms. Computer is the best known example of the use of ICT in education, but the term multimedia is also frequently used. Multimedia can be interpreted as a combination of data carriers, for example video, CD-ROM, DVD and internet and software in which the possibility for an interactive approach is offered (Smeets, 1996). Recently, ICT definition became more broadly used as Fong (2006) who explained that information and communication technology (ICT) is an umbrella term that includes any communication device or application, encompassing: radio, television, cellular phones, computer and network hardware and software, satellite systems and so on. In the context of (ICTs), virtually it deals with the software applications and computer hardware, and no doubt it became an essential part of the world of work in today's world. Derek, (2008) assumed that a modern labour market is almost unthinkable without ICT, digital literacy is increasingly considered as an essential competence.

\section{ICT IN SUDAN}

Sudan like other developing countries is still in the first steps of integrating ICT in teaching-learning process. Though it is limited by a number of obstacles. According to Hamdy 2007, in last two decades, Sudan's experience in building and capitalizing on ICT as gateway for custom development is benchmark in the country's history. The institutional, legal and governing framework was formed to advance ICT as a strategy for integrating the economy into the global market. The Sudanese national ICT strategy was formulated in the year 1999. This strategy focuses on five major areas, namely; technology infrastructure, human resource development, software industry development, content (primarily in Arabic), and geo-information (Hamdy 2007). The national policy encourages the use of ICT in developing local policies to ensure the complete integration of ICT in education and training on all levels, including the development of school curricula, 
teacher training, managing and organizing educational institutions (Abdelrahman, 2009). The ICT policy for education was launched in 2002. In 2004, ICT was introduced in secondary education curricula. A number of computers were installed in schools (around $50 \%$ of secondary schools), at an average of 10 computers per school. The internet connectivity is mainly through dial-up and Asymmetric Digital Subscriber Line (ADSL). However, in higher education systems, it is through ADSL only. The country is planning to have computers available in all education levels by the year 2015 as agreed at the ICT summit in Geneva. The ICT curriculum has been introduced at Grade 4. The teachers have been trained on the basics of ICT. Both the government and the private sector provide access to the internet as a learning resource (Hamdy 2007). The Ministry of Education has started providing schools and teachers' institutes with computers. There is an initiative for developing an educational management information system. The government has opened up competitive investments in telecommunication. License was granted for newcomers employing advanced technologies aiming at increasing the spread and access to ICT and make products affordable. Although there is an open market in internet service provision (El-Tigani, 2010), there is only one Internet Service Provider (ISP) - Sudanet ${ }^{1}$. The private sector is planning to open more Internet cafes in Khartoum. Development in ICT in Sudan is evident in a substantial expansion of infrastructure and capital investment including management systems and human capital (Elamin, 2004). According to Fatima, (2009) there are many constrains that hinder the best implementation of ICT throughout the country in spite of the promising efforts and policies made by the government and other bodies such as: Outreach to rural and remote areas still represents a considerable challenge. Poverty, lack of resources, and political unrest puts ICT lower on the priority list of basic needs in most areas of Sudan, civil war hinder nationwide implementation. In addition to the financing and donors interest in Sudan remains limited, especially with the number of restrictions that were imposed.

\section{OVERVIEW OF ICT IN SUDANESE HIGHER EDUCATION INSTITUTIONS}

The interest over training in ICTs has increased during the previous years to benefit from the development of these new technologies in teaching and lecturing. Accordingly, the demand on ICT training, design of the education system and all aspects of this global attitude has increased in Sudanese universities. Many studies recommend the introduction of ICTs to the higher education institutions (HEls) in Sudan. In this regard, Nour (2011) argued that introduction of ICTs to HEls is a very necessary requirement to achieve many objectives such as teaching staff and research environment development, a method to raise education quality and international standard in competitive world. He emphasized that the ICT has also the potential to support scientific research activities, improve the ways of acquisition of knowledge, and support the restructuring of administration and modernization of Sudanese universities. In the Sudanese HEls utilization of ICTs has proceeded rapidly in the past decade. Therefore, all the universities have Internet work services and connected together in one intranet. Hamdy, 2007, stated that the World Bank recommends that the HEls in Sudan, particularly specialized universities and colleges, have to use non-traditional higher education infrastructures with a view of availing more efficient modes of teaching and learning. But still there are many infrastructural, organizational and personal challenges and problems facing the use of ICTs. These obstacles found to be the lack of proximity to ICT facilities at the workplace and poor electricity supply, lack of funding, lack of university administrative support and low opportunities for training and lack of skilled and trained staff in using ICT tools. As Suliman et al., 2008 confirmed that the staff development program in Sudanese higher education is proposed to improve the ability of the teaching force and to provide them with new skills and teaching methods, pedagogy and psychology, application of teaching aids and the use of instructional Computers and Internet technologies. Nour Eldin et al. 2012 emphasized that despite the growing in the area of knowledge based systems, it is not known why the implementation of ICTs is still very low in Sudanese higher education's institutions.

\section{METHODOLOGY AND PARTICIPANTS}

Descriptive method and quantitative analysis of data were used in the study. The target sample of the study was 74 teachers. The sample was selected using stratified random sampling technique from eight faculties (see table 1 below). This research depended on primary data collected through a structured questionnaire prepared by the author to obtain information from a large group of staff in the University of Bahri during the first semester of academic year 2015-2016. Besides, the secondary data which was collected from internet, reports, and literature.

\footnotetext{
${ }^{1}$ banners.noticiasdot.com/termometro/.../aisi/.../aisi sudan.pdf
} 
Table1: Status of Respondents by Faculty ( $\mathrm{N}=74)$

\begin{tabular}{|c|c|c|c|}
\hline No. & Name of Faculty & Respondents & $\%$ \\
\hline 1 & Education & 15 & 20.3 \\
\hline 2 & Arts and Humanities & 8 & 10.8 \\
\hline 3 & Law & 9 & 12.2 \\
\hline 4 & Applied Sciences & 12 & 16.1 \\
\hline 5 & Natural Resources & 6 & 10.8 \\
\hline 6 & Animal Product & 7 & 8.1 \\
\hline 7 & Agriculture & 9 & 9.5 \\
\hline 8 & Engineering & $\mathbf{7 4}$ & 12.2 \\
\hline & Total & $\mathbf{1 0 0}$ \\
\hline
\end{tabular}

\section{DATA ANALYSIS}

The collected data is coded, entered into the computer and analysed using the Statistical Package for Social Sciences (SPSS) for Windows, version 16 and Excel program. Quantitative approach was used to answer the question about the use of the ICT in the lecture halls in Bahri University. Descriptive statistics are used to find out the distribution of respondents in the different categories. Tables, figures of frequencies and percentages are prepared.

\section{RESULTS AND DISCUSSION}

Results of this study were interpreted using descriptive statistics (frequencies and percentages) so as to give general overview of using ICT by the teachers in the University of Bahri - Sudan.

Table 2: Status of Respondents by Gender and Age ( $N=74)$

\begin{tabular}{|c|c|c|c|c|c|c|c|c|c|}
\hline \multicolumn{4}{|c|}{ Gender } & \multicolumn{2}{c|}{ Age } \\
\hline \multicolumn{2}{|c|}{ Male } & \multicolumn{2}{|c|}{ Female } & \multicolumn{2}{|c|}{$20-39$} & \multicolumn{2}{c|}{$40-59$} & \multicolumn{2}{c|}{60 - Over } \\
\hline $\mathbf{N}$ & $\%$ & $\mathbf{N}$ & $\%$ & $\mathbf{N}$ & $\%$ & $\mathbf{N}$ & $\%$ & $\mathbf{N}$ & $\%$ \\
\hline 45 & 60.8 & 29 & 39.2 & 40 & 54.1 & 31 & 41.8 & 3 & 4.1 \\
\hline
\end{tabular}

According to table 2 above, the results indicate that the majority of respondents were males $(60.8 \%)$. Also most of the respondents could be classified as young group of range of age (20-39 years) with a percentage $54.1 \%$. This situation means all of them and the next group (40-59) were familiar with using different kind of technologies as shown at figure 1 below.

Table 3: Status of Respondents by Job Title ( $\mathrm{N}=74)$

\begin{tabular}{|l|c|c|}
\hline \multicolumn{1}{|c|}{ Title } & Frequency & $\%$ \\
\hline Lecturer & 28 & 37.8 \\
\hline Assistant-Prof & 29 & 39.2 \\
\hline Associate-Prof & 11 & 14.9 \\
\hline Professor & 6 & 8.1 \\
\hline Total & $\mathbf{7 4}$ & $\mathbf{1 0 0 . 0}$ \\
\hline
\end{tabular}

Table.3 above indicates that all types of teaching staff (professors, associate-professors, assistantprofessors, and lecturers) have participated to this study. The majority was the assistant-professors group $(39.2 \%)$ and lecturers group $(37.8 \%)$. It's observed, that the number of the lecturers and the assistant professors is a big number in comparison to the number of associate professors and the professors. Such situation is normal and not intended due to the regulations of the promotion requirements of the university academic staff. 
Table 4: Number of Students in Classroom taught by Respondents

\begin{tabular}{|c|c|c|}
\hline Students & Frequency & $\%$ \\
\hline Less than 50 & 14 & 18.9 \\
\hline 50 to 100 & 9 & 12.2 \\
\hline 100 to 150 & 6 & 8.1 \\
\hline 150 to 200 & 9 & 12.2 \\
\hline Over 200 & 36 & 48.6 \\
\hline Total & $\mathbf{7 4}$ & $\mathbf{1 0 0 . 0}$ \\
\hline
\end{tabular}

Table 4 above showed that the bulk of the respondents (48.6\%) deals with a number of more than 200 students inside the classroom, thus situation needs non-traditional means for teaching, in another meaning, the blackboard or whiteboard is not appropriate and essential educational aids in the teaching and learning process. Therefore, the teachers need to use other tools like projector, LCD, mic...etc. Nevertheless, $18.9 \%$ of the respondents deal with less than 50 students in classroom; those might use traditional or non-traditional tools.

\section{INTEGRATION OF ICT IN TEACHING/ LEARNING PROCESS}

Table 5: Respondent's Ratings of using ICT in teaching \& Learning Process $(\mathrm{N}=74)$

\begin{tabular}{|c|l|c|c|c|c|}
\hline No. & \multicolumn{1}{|c|}{ Variables } & Yes & No & $\begin{array}{c}\text { I don't } \\
\text { know }\end{array}$ & Total \\
\hline 1 & $\begin{array}{l}\text { Do you use computer for presentation in the teaching } \\
\text { process? }\end{array}$ & $\begin{array}{c}64 \\
\mathbf{8 6 . 5} \%\end{array}$ & $\begin{array}{c}10 \\
\mathbf{1 3 . 5} \%\end{array}$ & - & $\begin{array}{c}74 \\
100.0 \%\end{array}$ \\
\hline 2 & Do you use ICT in teaching and learning process? & $\begin{array}{c}57 \\
\mathbf{7 7 . 0} \%\end{array}$ & $\begin{array}{c}17 \\
\mathbf{2 3 . 0} \%\end{array}$ & - & $\begin{array}{c}74 \\
100.0 \%\end{array}$ \\
\hline 3 & $\begin{array}{l}\text { Do you think that the use of ICT enhances the teaching } \\
\text { and learning process? }\end{array}$ & $\begin{array}{c}73 \\
\mathbf{9 8 . 6} \%\end{array}$ & - & $\begin{array}{c}1 \\
\mathbf{1 . 4} \%\end{array}$ & $\begin{array}{c}74 \\
100.0 \%\end{array}$ \\
\hline
\end{tabular}

According to table 5 above, $86.5 \%$ of the respondents confirmed they use the computer in presenting their lectures, while $13.5 \%$ were not. When they were asked of using the information and communication technology which is detailed in figure 1 below in teaching and learning process, $77.0 \%$ of the respondents rated: Yes, this means they prepare lessons in PPT format and browsing internet to increase knowledge and communicate with their students by email, WhatsApp...etc. The respondents who rated: No, some of them mostly belong to group 2 and group 3 of age (40-59) \& (60 - Over). They do not use computer in preparing lesson and only use the black or whiteboard in the teaching and learning process. However, when the respondents were asked; (Do you think that the use of ICT enhances the teaching and learning process?), about $98.6 \%$ rated Yes: that means they emphasized the importance of using the ICT in enhancing the teaching and learning process, even those who have no relationship with computer and other ICT technology. Only one respondent said there is no impact of using ICT in enhancing the teaching and learning process. 


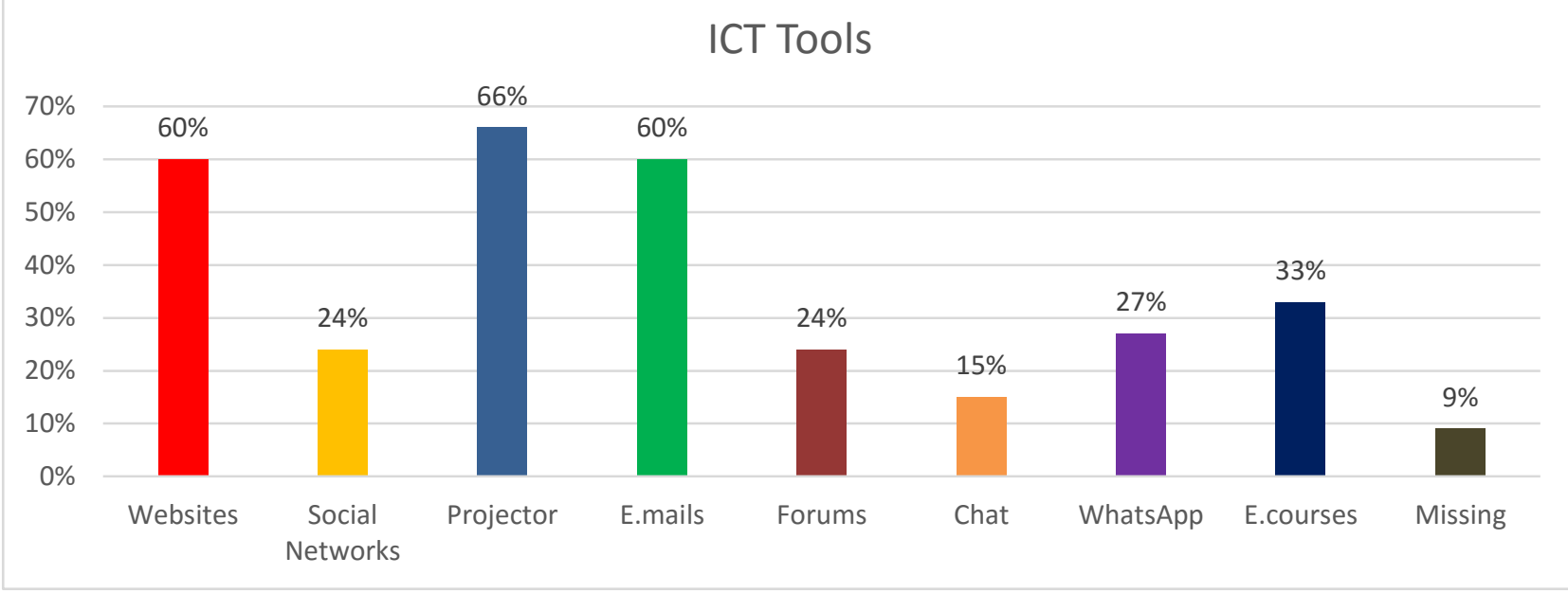

Fig.1.Rank of using ICT tools by Respondents

Figure 1 over shows the preference of using the ICT tools by the academic staff in the University of BahriSudan, where $66 \%$ of the respondents use the projector in presenting lessons. $60 \%$ browsing the internet using relevant websites to their fields and the same percentage uses emails for different purposes. Nonetheless, respondents use various forms of ICTs to communicate with others inside the Sudan and worldwide.

\section{CONCLUSION}

The rapid development in ICT has brought significant changes in the twenty-first century, as well as affected its adoption and integration by teaching staff in teaching-learning process. The effective integration of technology into classroom practices represents a challenge to teaching staff. The findings of this study indicate that teaching staff have solid desire for the integration of ICT into education but they encountered by many obstacles such as technical problems related to electricity and disadvantage of projector devices, illiteracy of some academic staff concerning the dealing with computer and some software like power point and statistics programs. Finally, the old generation of teachers resists using the ICT in teaching process. These findings have implications for encouraging teachers to use of ICT especially the old individuals focusing on obtaining basic ICT skills.

\section{RECOMMENDATIONS}

The use of the new technology for education has become well-recognized world-wide, and from now on all aspects of life could be unthinkable without ICT. There is an international consensus that the use of computer in teaching-learning process has grown more diversified as educators recognize the potential of learning with technology as a tool for enhancing students' capabilities.

University of Bahri as a new established university in Sudan is still facing great challenges, and in particular, the adoption of new technology into the teaching process. This challenge requires equipping the lecture halls with the suitable computer equipment to enabling teaching and learning in computer programs. It is also recommended developing new curricula and using ICT as presentation tools. Most important is to motivate and reward teaching staff to use ICT. Moreover, is the Integration of the ICT into the university strategy is highly needed. Finally, transformation of positive attitudes towards ICT into effective practices is recommended.

\section{REFERENCE LIST}

Abdelrahman, O. (2009). The state of ICT Implementation and Training at the University of Khartoum Library System. Khartoum-Sudan: University of Khartoum Library System. http://crl.du.ac.in/ical09/papers/index files/ical12 $63 \quad 164 \quad 1$ RV.pdf.

Bashir, Y. H. (2006). The History of Technical Education in Sudan. Alsudani Newspaper, 27-28 Issue No. 409 and Issue No. 410.

Derek, E. (2008). Relevant and Interactive Usage to Improve TVET- Research and Networking. International Conference of Senior Administrators, policymakers, Researchers and other practioners. Bali, 
Indonesia.

Elamin, A. (2004). Promoting ICT for Human Development in Sudan. ICS Portal for Technology Transfer, http://www.ics.trieste.it/Documents/Downloads/df2124.doc.

El-Tigani, M. E. (2010). Sudan Internet and sd. Experience. Innovation and Excellence. Khartoum-Sudan: http://www. itu.int/itudoc/itu-t.

Fatima, A. (2009). Using ICT on Empower Women in Sudan. Regional Fallow-up to the outcomes of the World Summit of the International Soceity

Fong, J. C. (2006). Integrating ICT into Teaching and Learning Concepts, implementation and Challenged: A Bruneian Perspective. National Conference on ICT in Education. Brunei Darussalam: International Convention Centre Berakas, BSB

Guma, et al. (2013) The Role of ICT to Make Teaching-Learning Effective in Higher Institutions of Learning in Uganda.

Hamdy, H. (2007). ICT in Education in Egypt, Survey of ICT and Education in Africa: Egypt Country Report. www.infodev.org. Washington: The World Bank. Vol. 53.

Hamdy, H. (2007). ICT in Education in Sudan, Survey of ICT and Education in Africa:Sudan Country Report. www.infodev.org. Washington: The World Bank. Vol. 53.

http://css.escwa.org.lb/ictd/850/Track3/Fatima Abdel Mahmoud ICT to Empower Women in Sudan.pdf). Damascus: ITU-UNESCO.

http://smrimba.net/Document/ICTIntegration.pdf

Initiative, E. E. (2008). Egyptian Education Initiative. Cairo-Egypt: World Economic Forum. http://www.eei.gov.eg/pages/01\%20About\%20EEl/Overview.aspx

Nour Eldin, et al.(2012) Challenge Facing Sudanese higher education institutions for implementing the Knowledge Based Systems

Nour, S. O. (2011), The use and economic impacts of information and communication technology (ICT) in Sudan, United nation university, Maastricht economic and social research institute on innovation and technology (UNU-MERIT), Netherlands

Smeets, E. (1996). Multimedia op school. Nijmegen. Instituut voor Toegepaste Sociale Wetenschappen, Ubbergen: Tandem Felix.

Smeets, E. T. Et al (1999). The Impact of Information and Communication Technology on the Teacher. Institute for Applied Social Sciences (ITS); University of Nijmege.

Suliman, A., Raman, M., and Hamid, R. (2007), ICT for higher education in Sudan: Issues and perspectives, managing worldwide operations and communications with information technology, Multimedia University, Malaysia 